\title{
逆Stenvers氏撮影法の有用性の検討
}

\author{
丸山裕稔・井手口忠光 ${ }^{1)} \cdot$ 大浦弘樹 $^{2)} \cdot$ 東 敏也 ${ }^{3)}$ \\ 折田信一 ${ }^{4)} \cdot$ 天野一弘 $^{5)} \cdot$ 東田善治 $^{6}$ \\ 国立熊本病院放射線科 \\ 1 ) 国立病院九州医療センタ一放射線部(臨床研究部) \\ 己)国立病院九州がんセンタ一放射線科 \\ 3) 宮崎医科大学附属病院中央放射線部 \\ 4)国立病院九州循環器病センタ一放射線科 \\ 5)国立療養所再春荘病院放射線科 \\ 6) 九州大学医学部保健学科放射線技術科学専攻
}

繒

耳鼻科領琙に抢ける聴器, とりわけ錐体(内耳道, 三半規管) 撮影に抏いては, Stenvers氏撮影法 (以下 Stenvers法)が一般的に用いられてる。耳鼻科専門医に よる読影では，左右内耳の比較読影を行うことが多 く，対称に撮影することは特に重要である。しかし， Stenvers法は腹臥位で頭部正中を傾ける等のポジショ ニングが要求されるため, 再現性よく解剖学的位置関
係を左右対称にしかも正確に描出することは難しく， 熟練を要する。また，めまいを伴う患者や高齢者で は, 腹卧位が困難な場合も臨床の現場では数多く遭遇 する。このような場合, Stenvers法に代わってポジシ ヨニングが比較的簡便で，患者の苦痛も少なく仰臥位 または座位で撮影可能な逆Stenvers氏撮影法(以下，逆 Stenvers法)がしばしば用いられる。しかしながら，こ の撮影法はStenvers法に比べ錐体の拡大率の増加や水

\section{Usefulness of the Opposite Direction for Stenvers' Method}

\author{
HIROTOSHI MARUYAMA, TADAMITSU IDEGUCHI, ${ }^{1)}$ HIROKI OHURA, ${ }^{2)}$ \\ TOSHIYA AZUMA, ${ }^{3)}$ SHINICHI ORITA, ${ }^{4)}$ KAZUHIRO AMANO,5) \\ and YOSHIHARU HIGASHIDA ${ }^{6)}$
}

Department of Radiology, National Kumamoto Hospital

1) Department of Radiology, National Hospital Kyushu Medical Center

2)Department of Radiology, National Hospital Kyushu Cancer Center

3) Department of Radiology, Miyazaki Medical College Hospital

4) Department of Radiology. National Hospital Kyushu Cardiovascular Center

5) Department of Radiology. National Alcoholism Saisyunsou Hospital

6) Department of Radiological Sciences. School of Health Sciences. Faculty of Medicine,

Kyushu University

Received Jan. 20, 2003; Revision accepted March 29, 2003; Code No. 241

\section{Summary}

In otorthinolaryngology, Stenvers' method is employed in radiography of the pyramid(internal acoustic meatus and semicircular canals). However, in cases of dizziness, where the prone position is difficult to achieve, we occasionally use the opposite Stenvers' method instead of the conventional one. This makes it possible to perform radiography with the patient in the supine position. Compared with the conventional Stenvers' method, the problems of this method were increases not only in the rate of magnification but also in lens dose. In this study, we evaluated these problems by employing computed tomography $(\mathrm{CT})$ and a glass dosimeter with phantom as well as by clinical evaluation. The results showed no statistically significant difference between Stenvers' method and the opposite Stenvers' method in both the rate of magnification and the clinical evaluation. The increase in lens dose with the opposite Stenvers' method was not significant. We concluded that the opposite Stenvers' method was useful.

Key words: Opposite Stenvers' method, Stenvers' method, Angle of pyramid, Lens dose 


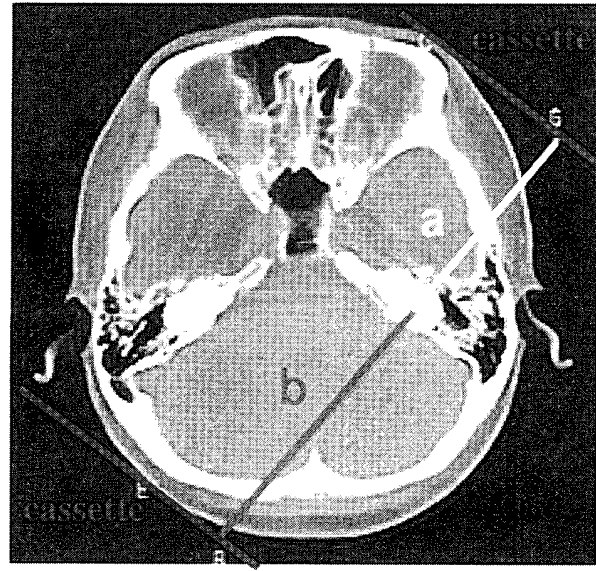

(a)

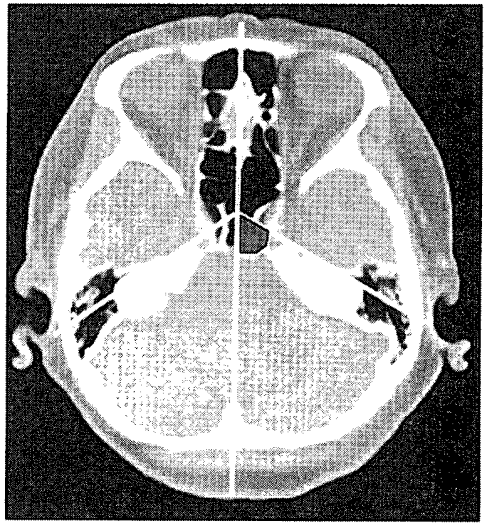

(b)

Fig. 1 Measurements of rate of magnification (a) and pyramidal angle (b). We measured an angle consisting of a perpendicular line to the superior semicircular canal and a median line.

晶体の被曝線量増加，内耳道，三半規管のひずみや描 出不良が考えられ，一般的には推奨されていない。本 研究の目的は, これらの問題点を頭部CT画像を用い て, 錐体の正中軸からの角度や拡大率の計測を行い統 計学的に解析し, 逆Stenvers法の有用性を検討するこ とである。また，Stenvers法と逆Stenvers法を用いて 撮影された，X線画像の視覚評価および水晶体の被曝 線量も測定し，あわせて検討した。

\section{1. 使用機器および方法}

\section{1-1 頭部正中軸傾斜角の計測および錐体拡大率}

Stenvers法㧍よび逆Stenvers法の撮影時における適 正な頭部正中軸傾斜角を求めるために, CT画像を用 いて，錐体の正中軸からの角度を計測した．対象は， 国立熊本病院で2000年 7 月から2000年 9 月までに頭 部CT検査を受けた患者45名で，その内訳は男性22名 (平均年齢 $58.2 \pm 23.6$ 歳)，女性 23 名 (平均年齢 $58.6 \pm 24.6$ 歳)，である。使用したCT装置は日立社製 CT-W2000である。計測の方法は，まずCT画面上で上 半規管に対し垂直な直線を引き，その線と頭部正中線 のなす角度を錐体角度とした (Fig. $1(\mathrm{a}))$. 求めた角度 の左右差挹よび性別による差の統計解析を行った。用 いた統計解析方法はスチューデントの $\mathrm{t}$ 検定で，危険 率 $5 \%$ 以下を有意差ありとした。拡大率についても同 様にCT画面上で, Stenvers法, 逆Stenvers法に扔ける カセッテ面の位置を想定し，カセッテ面を錐体に対 し，平行に配置したときの三半規管からカセッテ面ま での距離を，それぞれa，bとし拡大率を求めた(Fig. 1 (b)). 拡大率を求めるときの焦点一フィルム間距離は
$120 \mathrm{~cm}$ とした

\section{1-2 水晶体被曝線量}

水晶体被曝線量は, 頭部ファントム(京都科学社製 頭部ファントム)を用いて測定を行った。水晶体の位 置にガラス線量計の素子を配置し，臨床と同条件で Stenvers法, 逆Stenvers法のポジショニングを行い撮 影を行った。照射野はカセッテ面上で, 眼窩外側から 乳突蜂巣㧍よび乳様突起を含む $10 \mathrm{~cm} \times 11 \mathrm{~cm}$ とした。 その配置図およびその照射野で撮影したX線写真を Fig. 2(a)，（b)に示す。撮影に使用したX線管球は CIRCLEX 0.5/IP33C，X線発生装置は島津社製 UD150L-30で, 撮影条件 $74 \mathrm{kV}, 160 \mathrm{~mA}, 80 \mathrm{msec}$, FFD (film focus distance) $=120 \mathrm{~cm}$ にて撮影を行った。 水晶体被曝線量, およびバックグランドの測定には, それぞれ五つのガラス素子を使用した。また測定值の 平均值からバックグランドの平均值を差し引いた值 を，水晶体被曝線量とした。また，使用したガラス線 量計は千代田テクノルDose Ace GD-352Mであり，ガ ラス素子の性能は, 測定線種X線：15keV〜20MeV, 測定線量範囲：10 $\mu \mathrm{Gy} \sim 500 \mathrm{~Gy}$ である.

\section{1-3 臨床評価}

臨床におおける逆Stenvers法の有用性を検討するため に，専門医による視覚評価を行った，対象は健常ボラ ンティア16名で, その内訳は男性 6 名 (平均年齢 $51.8 \pm 15.1$ 歳)，女性 10 名 (平均年齢58.5 15.4 歳)であ る.まず，2-1の結果(錐体角度)をもとに, Stenvers法 㧍よび逆Stenvers法を用いて同一対象者の右側のみの 


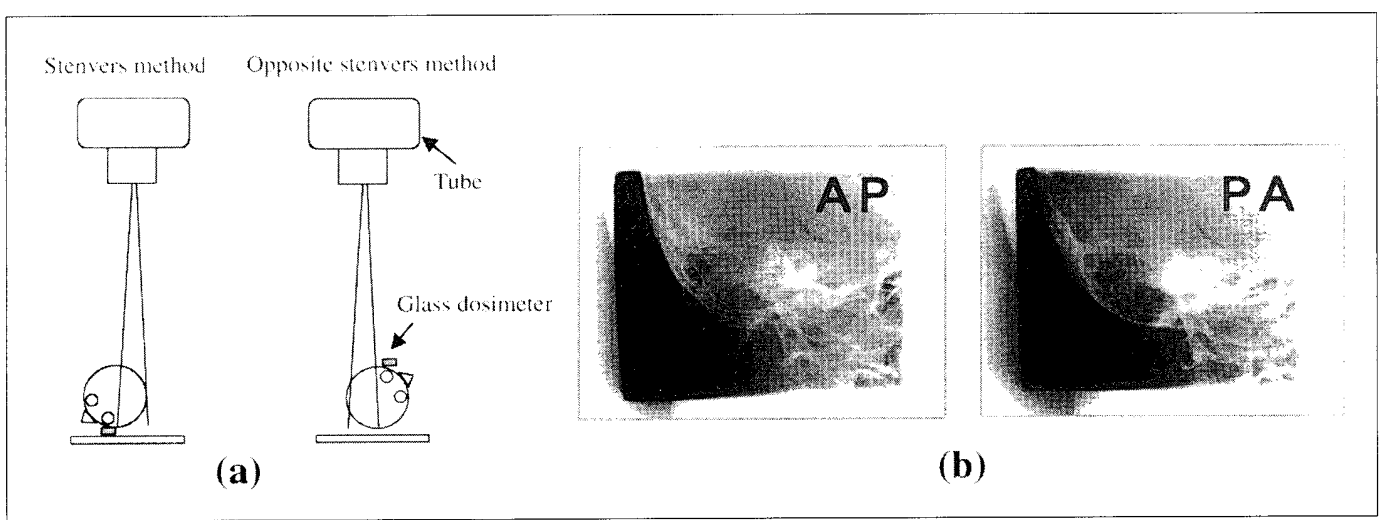

Fig. 2 Position of glass dosimeter (a), field of exposure dose measurement $(10 \mathrm{~cm} \times 11 \mathrm{~cm})(\mathrm{b})$. The glass dosimeter was positioned to a phantom of the lens.

撮影を行った。評価の方法は, 得られた逆Stenvers, Stenvers法のX線画像計32枚を用い, 経験年数 2 年以 上の放射線科医 3 名扔よび耳鼻科医 4 名による 3 段 階 $(1=\operatorname{good}$ : 内耳道, 三半規管が正確に描出され十分 に診断可能である. 2=adequate：内耳道，三半規管は ある程度描出され，診断は可能である。 3=poor：内耳 道, 三半規管のどちらかの描出が悪く診断が困難であ る)の視覚評価を行った. Stenvers法および逆Stenvers 法の描出能の差は, 視覚評価により得られた結果を Mann-Whitney検定を用い危険率 $5 \%$ 以下を有意差あり とした。 な拀，撮影に際しボランティア16名に，研究 の趣旨を説明し，同意を得た。

\section{2. 結 果}

\section{2-1 頭部正中軸傾斜角および錐体拡大率}

Fig. 3に対象45名のCT画像より計測した, 錐体と頭 部正中線のなす角度 (以下, 錐体角度)の結果を示す。 得られた角度の平均は, 左錐体角度 $50.8 \pm 3.35$ 度, 右 錐体角度49.6 23.25 度となり, 検定に扔いて両者間に 有意な差は認められなかった，以上のことょり，左右 の錐体角度に差はないとの結果が得られた。また平均 の錐体角度は約50度でありここれにより撮影時に扔け る頭部正中軸の傾斜角は，40度が最適であるとの結果 が得られた。

Fig. 4，5には男女別の錐体角度をそれぞれ左右別に ヒストグラムで示す。左錐体角度は男性平均 $50.9 \pm 3.81$ 度, 女性平均 $50.6 \pm 2.91$ 度, 右錐体角度は男 性平均 $49.9 \pm 3.51$ 度, 女性平均 $49.4 \pm 3.03$ 度となり, 検 定に打いて男女間に有意な差は認められなかった。

次に錐体の拡大率は, CT画像上り求めた対象45名 の平均では, 逆Stenvers法=1.09 0.04 , Stenvers法 $=1.07 \pm 0.03$ 倍となり, 逆Stenvers法がわずかに拡大率 は大きかった。

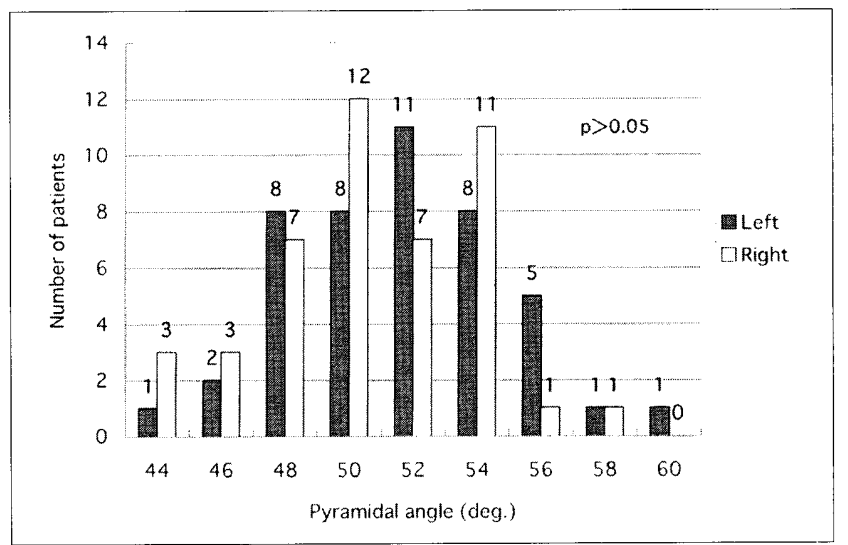

Fig. 3 Distribution of pyramidal angle measurements in 45 patients.

There was no difference between the two methods.

\section{2-2 水晶体被曝線量}

水晶体被曝線量の結果をTableに示す. Stenvers法, 逆Stenvers法それぞれにおける五つのガラス素子の読 み取り值と, バックグランドの值, その平均值を表示 した。読取值の平均は逆Stenvers法で $47.6 \mu \mathrm{Gy}$, Stenvers法では $33.4 \mu \mathrm{Gy}$ となり, バックグランドの平 均 $31.6 \mu \mathrm{Gy}$ を差し引くと, 水晶体被曝線量は逆 Stenvers法 $=16.0 \pm 1.85 \mu \mathrm{Gy}$, Stenvers法 $=1.80 \pm 0.49 \mu \mathrm{Gy}$ であった。得られた結果より水晶体の被曝線量は逆 Stenvers法がStenvers法の約 9 倍の増加となった。

\section{2-3 臨床評価 (視覚評価)}

逆Stenvers法およびStenvers法の臨床における視覚 評価の結果をFig. 6に示す. Stenvers法におけるgoodの 評価は67.9\%, 逆Stenvers法は56.3\%であり, 従来の Stenvers法が明らかに高率であった。しかし診断可能 なgood とadequateの評価を合わせると, Stenvers法は $87.5 \%$, 逆Stenvers法が $88.4 \%$ と逆Stenvers法の評価が 


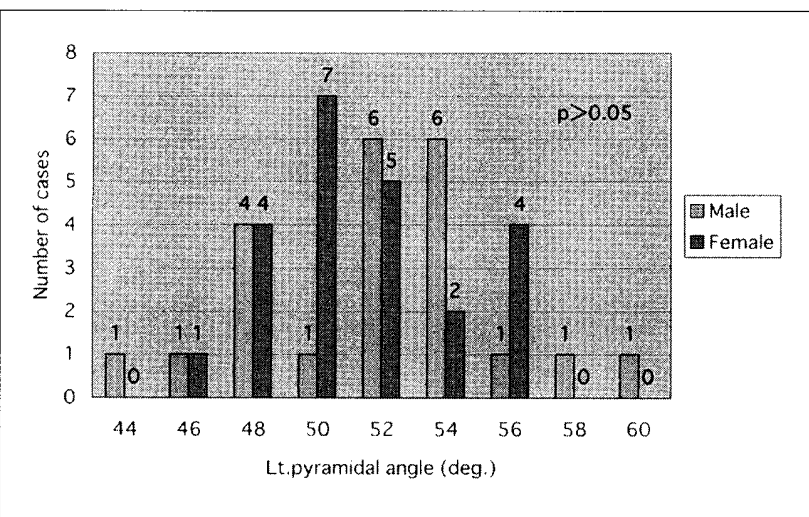

Fig. 4 Sex distribution by left pyramidal angle. There was no difference between the two methods.

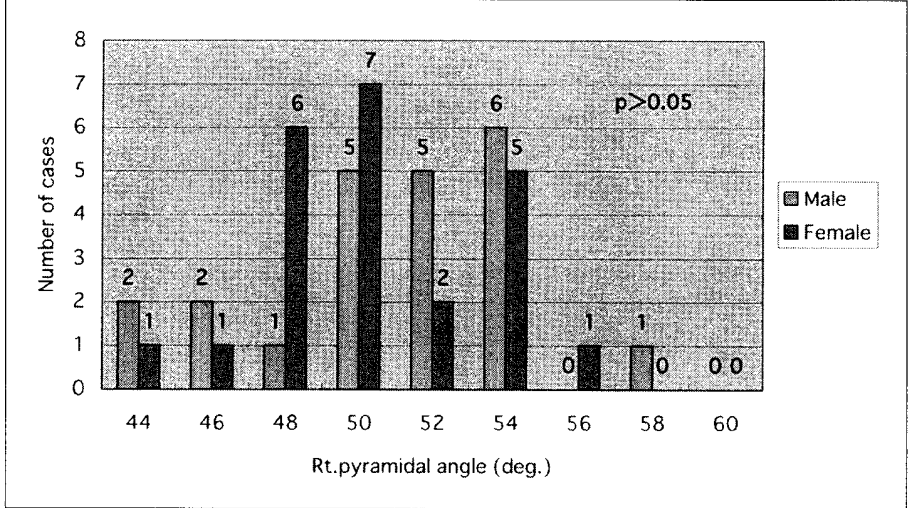

Fig. 5 Sex distribution by right pyramidal angle. There was no difference between the two methods.

Table Results of lens dose measurement.

\begin{tabular}{|c|c|c|c|c|c|c|c|}
\hline & \multicolumn{6}{|c|}{ Read dose ( $\mu \mathrm{Gy})$} & \multirow{2}{*}{ Lens dose ( $\mu \mathrm{Gy})$} \\
\hline & 1 & 2 & 3 & 4 & 5 & AVE & \\
\hline $\begin{array}{l}\text { Opposite stenvers } \\
\text { method }\end{array}$ & 47 & 51 & 46 & 46 & 48 & 47.6 & $16.0 \pm 1.85$ \\
\hline Stenvers method & 33 & 34 & 33 & 33 & 34 & 33.4 & $1.8 \pm 0.49$ \\
\hline Back ground & 28 & 34 & 33 & 33 & 30 & 31.6 & \\
\hline
\end{tabular}

高かった。しかし，その差は $0.9 \%$ とわずかであり， ほほ同等の評価であると思われる，診断が困難なpoor の評価では従来のStenvers法が12.5\%，逆Stenvers法が $11.6 \%$ とその差は $0.9 \%$ ありりこの差もわずかであ った。ちなみに検定においては，両者間に有意な差は 認められなかった。Fig.7にはgood, Fig. 8にはadequateの評価を受けた症例を，またFig.9にはpoorの評 価を受けた逆Stenvers法およびStenvers法の症例を供 覧する。

\section{3. 考 零}

難聴，耳鳴，耳閉感，めまい等の異常を伴う臨床像 は，聴神経腫瘍が疑われ1，2)単純X線撮影法の一つで あるStenvers法がスクリーニング検査として，通常選 択されている。しかし，Stenvers法は，ポジショニン グが非常に困難であり，患者の苦痛も大きく，診断に 適した画像を得るには熟練を要する撮影法の一つであ る。そこで今回，ポジショニングも簡便で患者の苦痛 も小さい, 逆Stenvers法の臨床的有用性を検討した。 検討した項目は，正中軸傾斜角度，拡大率，水晶体被 曝線量, 描出能(視覚評価)である.

まず正中軸傾斜角度は，男女合計45名を対象に計測 を行った結果, 平均で左錐体角度 $50.8 \pm 3.35$ 度, 右錐 体角度49.6土3.25度となった。また，検定により錐体

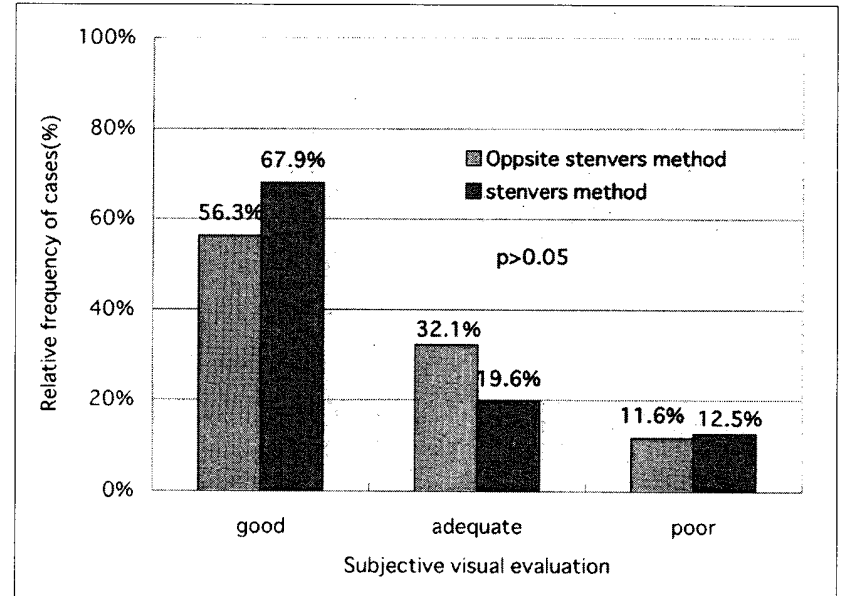

Fig. 6 Results of clinical evaluation.

Results of the clinical evaluation were practically the same.

角度に，性差および左右差は認められなかった。以上 の結果より, 錐体角度は約50度であり, 撮影時の正中 軸傾斜角度は40度が適当であるとの結果が得られた。 従来からの成書には，正中軸傾斜角度は45度と記載さ れている3４．しかしそれらは，頭部断面において長 軸方向に比較的長い外国人がモデルである。外国人に 比べ，短軸方向に比較的長い日本人には錐体をカ七ッ テに平行にポジショニングするには，45度という角度 


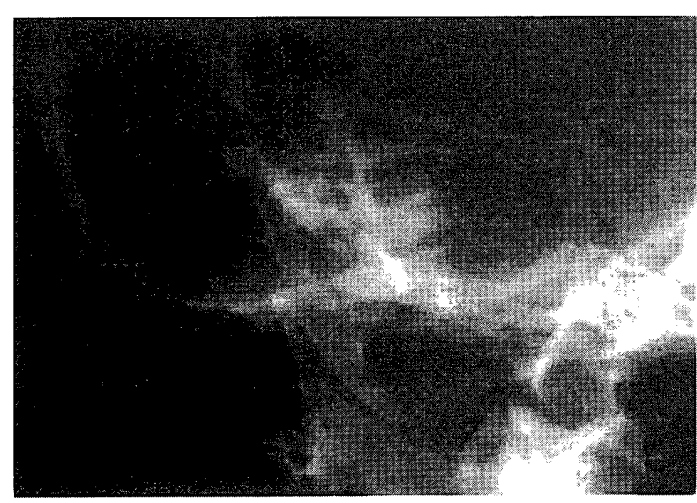

Opposite stenvers method

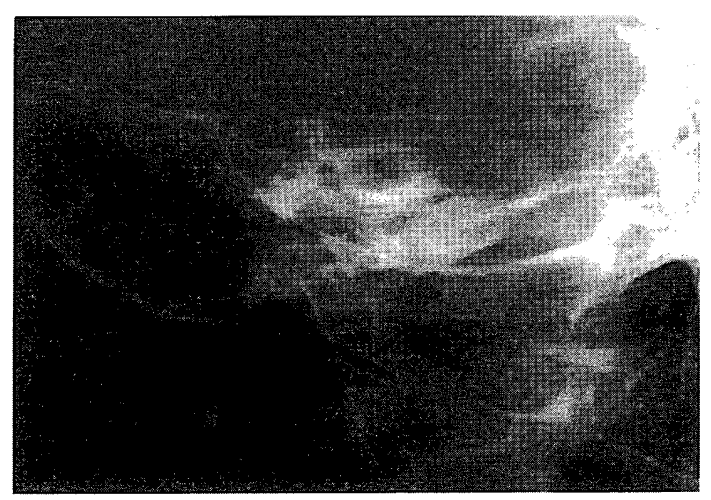

Stenvers method

Fig. 7 Clinical radiography was evaluated as "good". Internal occipital crest was out of the lateral semicircular canal.

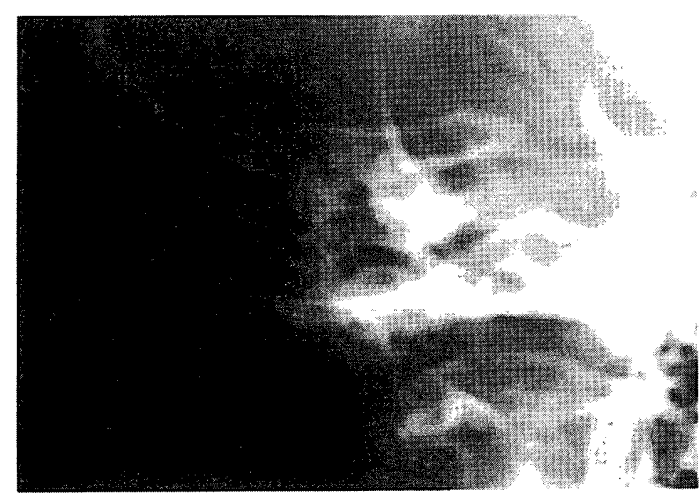

Opposite stenvers method

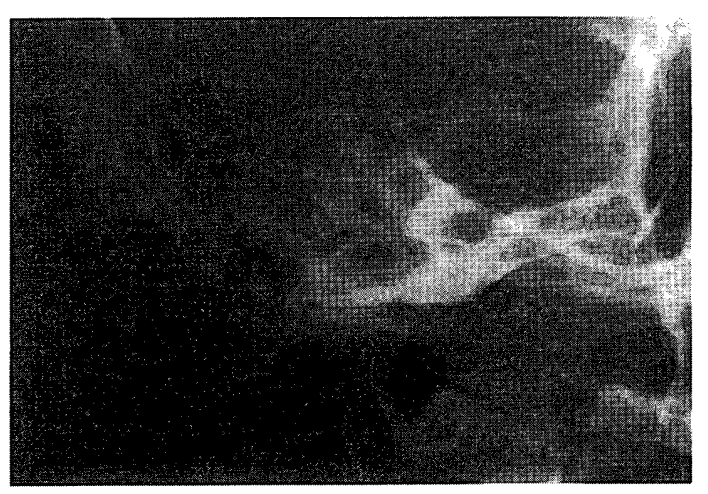

Stenvers method

Fig. 8 Clinical radiography was evaluated as"adequate".

Internal occipital crest was on the internal acoustic meatus.

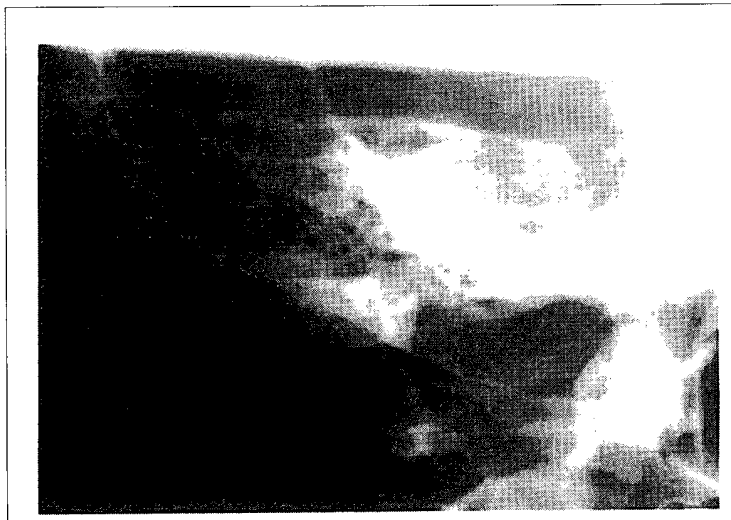

Opposite stenvers method

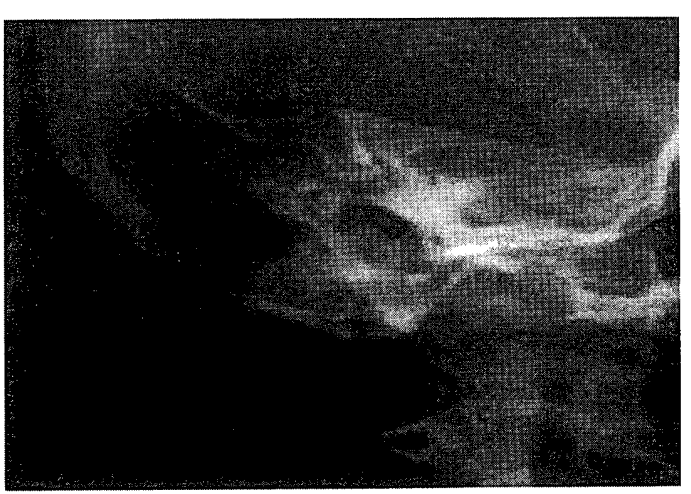

Stenvers method

Fig. 9 Clinical radiography was evaluated as "poor".

Internal occipital crest was on the fundus of the internal acoustic meatus and vestibule. 
は不適当であると考えられた。耳鼻科専門医による と, 内後頭陵を外側半器官の外側に描出するために, 正中線を傾けすぎるのは，内耳道を短縮して描出する ため, 内耳道の評洒には好ましくない。また一番重要 なのは，左右対称に撮影することであるという意見で あった。

錐体の拡大率は平均で, 逆Stenvers法 $=1.09 \pm 0.04$, Stenvers法=1.07士0.03であり，わずかに逆Stenvers法 の拡大率が大きいものの, 読影診断に際してほとんど 問題ない差であると考えられた。

次に水晶体被曝線量は, 逆Stenvers法 $=16.0 \pm 1.85 \mu \mathrm{Gy}$, Stenvers法 $=1.80 \pm 0.49 \mu \mathrm{Gy}$ という值 が得られた。逆Stenvers法がStenvers法に比べ約 9 倍 の被曝線量の増加であるが, 白内障発生のしきい值 $0.15 \mathrm{~Gy}$ と比較しても，ほとんど問題ない值であっ た。ちなみに，1990年(Pub.60)のICRP(International Commission on Radiological Protection : 国際放射線 防護委員会)の勧告によると, 一般公衆の線量限度に おける水晶体等価線量は， $15 \mathrm{mSv} /$ 年とされており， その值と比較しても約1000分の 1 の值であった。臨 床の現場に掞いて，実際に撮影を行う場合，逆 Stenvers法では術者は自分の目で被写体の眼窩が確認 できるため，水晶体にX線が照射されないように，容 易にコリメーションを行うことができる。しかし，

Stenvers法では, 術者は眼窩の確認が不可能であるた め,コリメーションは経験および勘に頼る場合が多 く, 必然的にStenvers法が逆Stenvers法に比べ，水晶 体被曝線量は増加するケースが多くなるとも考えられ た。

最後に同一症例16名におういて, 逆Stenvers法および Stenvers法にて撮影された画像の視覚評価の結果は, 診断可能と判断されたgoodとadequateの評価を合わせ ると, Stenvers法は87.5\%, 逆Stenvers法が88.4\%とわ ずかに逆Stenvers法の評価が高かった。しかし，その 差は $0.9 \%$ とわずかであり, 両者の画像にほとんど差 はないと考えられた。逆Stenvers法は, 後頭稜の位置 がカセッテに近いため, 正中軸傾斜角度40度を用い た場合，Stenvers法に比へ，比較的後半規管と重なり やすい傾问にあった。しかし今回の専門医による評価
では，それらの症例もほとんどが診断可能と評価され ており, 内耳道の描出を中心に評価しており，診断へ の影響は少ないと考えられた。

Stenvers法を用いて撮影された, 内耳道径の左右差 が $2 \mathrm{~mm}$ 以上を有意とした場合 ${ }^{5,6)}$, 一側聴神経腫瘍

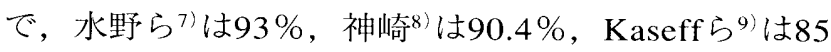
\%に異常が認められたと報告している。相原らはは, 単純撮影はどの医療機関でも容易にかつ安価に行い得 る検査であり，聴神経腫瘍の早期診断にあたっては Stenvers法が極めて有用と考えられ，注意深く読影す ることが大切であるとも報告している。伊藤ら ${ }^{10)}$ は最 近では聴覚系の諸検査やMRIの導入により内耳道内に 限局する小さな聴神経腫瘍も診断が可能となったが, 患者すべてにMRI検査を行うことは現実的には不可能 であると述べている。それゆえに，難聴，耳鳴，耳閉 感，めまい等の症状を伴う患者のスクリーニングに は, Stenvers法が選択されることが多く，左右対称に 撮影することは読影診断にとって特に重要となる。し かし，われわれ放射線技師にとって，Stenvers法を用 いて, 左右対称に内耳道を撮影することは, かなりの 熟練を要する。

今回検討を行った逆Stenvers法はポジショニングが 簡便で，患者の苦痛も少なく仰臥位または座位で撮影 可能であり, 熟練を要することなく, 再現性よく解剖 学的位置関係を左右対称にしかも正確に描出すること ができ, 日常臨床に扔いて非常に有用な撮影法である と考える.

\section{4. まとめ}

逆Stenvers氏撮影法は, Stenvers氏撮影法との比較に おいて, 拡大率, 被曝線量, 臨床視覚評価ともに問題 なく，ポジショニングも簡便であり，患者の苦痛も少 ない撮影法である。

以上のことより, 逆Stenvers氏撮影法は日常臨床に おいて, 非常に有用な撮影法であると考えられる。

\section{謝 辞}

稿を終えるにあたり，ご協力いただいた株式会社千 代田テクノル 萱野信二氏に, 深く感謝いたします。 


\section{参考文献}

1) 相原康孝, 神尾友和：当院に扔ける聴神経腫瘍症例の検 討. 耳鼻臨床，88(11)1395-1401，(1995)。

2) Naunton RF, and Petasnick JP: Acoustic neurinomas with normal internal auditory meatus. Arch Otolaryngol, 91, 437443, (1970).

3) Philip w. Ballinger: Temporal bone: Merrill's atlas of radiographic positions and radiologic procedures volume two, 448449, The C.V.Mosby Company, St.louis.Toronto.London, (1982).

4) 飯沼壽孝：ステンバース法. 耳と鼻のレントゲン写真, 13 16, エッセクス日本株式会社, 東京, (1987).

5) 小寺一興, 飯沼壽孝: 内耳道のX線診断一普通X線撮影に 抢ける内耳道正常值一。耳鼻臨床，67，697-706, (1974).
6) Thomsen J, Reiter S, Borum P, et al.: Tomography of the internal acoustic meatus. J Laryngol Otol, 95, 1191-1204, (1981).

7) 水野正浩, 室伏利久：単純X線写真における内耳道につい て. Otol Jpn, 4, 74-77, (1994).

8）神崎 仁：聴神経腫瘍の外科的治療に関する研究. 耳展33 補3，243-523，(1990).

9) Kaseff LG, Perkins R, and Hambley WH: Radiological techniques for small acoustic tumors: a re-evaluation. Laryngoscope, 91, 63-70, (1981).

10) 伊藤信輔, 安本誠司, 山口勝矢：聴神経腫瘍の診断一経迷 路的手術例における検討一。耳鼻，38，606-610, (1992).

Fig. 1 拡大率の測定 $(\mathbf{a})$ ，錐体角度の測定 $(\mathbf{b})$

錐体角度は，上半器官に対し垂直な線と，正中線とのなす角を測定.

Fig. 2 ガラス線量計配置図 (a), 被曝線量測定時の照射野 $(10 \mathrm{~cm} \times 11 \mathrm{~cm})(\mathrm{b})$

線量計は照射野外に配置，水晶体(眼窩)は照射野に含まない。

Fig. 3 対象者の錐体角度の分布

両者間に有意な差は認められなかった。

Fig. 4 錐体角度の性別による分布(左)

男女間に有意な差は認められなかった。

Fig. 5 錐体角度の性別による分布 (右)

男女間に有意な差は認められなかった。

Fig. 6 臨床に扮ける視覚評価の結果 ほぼ同等の評価である。

Fig. $7 \operatorname{good} の$ 評価を受けた臨床写真 内後頭陵が外側半器官の外側に描出されている

Fig. 8 adequateの評価を受けた臨床写真

内後頭陵が内耳道と重なっている.

Fig. 9 poorの評価を受けた臨床写真 内後頭陵が内耳道底および前庭に重なって描出されている。

Table 水晶体被曝線量測定結果 